\title{
T Lymphocyte Subpopulations in Normal Pregnancies and Those Complicated by Eclampsia in Kaduna State, Nigeria
}

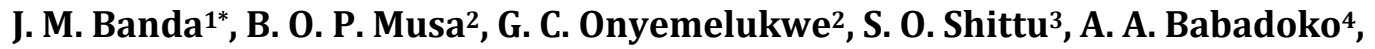 \\ A. G. Bakari' ${ }^{2}$, A. I. Mamman ${ }^{4}$, A. Sarkin-Pawa3 ${ }^{3}$, Surajudeen A. Junaid ${ }^{5}$ \\ ${ }^{1}$ Department of Chemical Pathology and Immunology, Barau DikkoTeaching Hospital, Kaduna State University, \\ Kaduna, Nigeria \\ ${ }^{2}$ Department of Medicine, Immunology Unit, Ahmadu Bello University Teaching Hospital, Zaria, Nigeria \\ ${ }^{3}$ Department of Obstetrics and Gynaecology, Ahmadu Bello University, Zaria, Nigeria \\ ${ }^{4}$ Department of Haematology and Blood Transfusion Services, Ahmadu Bello University, Zaria, Nigeria \\ ${ }^{5}$ Department of Virology, Federal College of Veterinary and Medical Laboratory Technology, National \\ Veterinary Research Institute, Vom, Nigeria \\ Email: "jimbanda31@yahoo.com
}

Received 4 March 2016; accepted 14 August 2016; published 17 August 2016

Copyright ( 2016 by authors and Scientific Research Publishing Inc.

This work is licensed under the Creative Commons Attribution International License (CC BY).

http://creativecommons.org/licenses/by/4.0/

cC) (i) Open Access

\section{Abstract}

Background: Eclampsia, the occurrence of generalized convulsion(s) in association with signs of preeclampsia [PE] (hypertension and proteinuria) in pregnancy has remained a significant public threat in Nigeria, contributing to maternal and perinatal morbidity and mortality. This study was a comparative cross-sectional study conducted in some selected hospitals in Kaduna State, between April 2014 and November 2015. Subjects and Methods: Blood (3 mls) was collected into an ethylenediaminetetraaccetic acid (EDTA) vacutainer tube from third trimester women diagnosed with eclampsia (EC; $n=38$ ) and healthy pregnant controls (PC; $n=38$ )-age and parity matched and healthy non-pregnant controls (NPC; $n=38$ )-age matched. $T$ Cell subpopulations and Complete Blood Count levels were measured by Sysmex, Auto blood analyzer and flow cytometry respectively. Participants with smear positive malaria, seropositive for human immunodeficiency virus (HIV), any other clinical infection or refused consent were excluded from this study. Data obtained were analyzed using analysis of variance (ANOVA) and Post Hoc test. A p-value of less than 0.05 was considered to be significant. Result: Overall, results showed a depressed (mean \pm Standard deviation (SD): CD3 + T cell $(65.6 \pm 15.5 \% ; 1225.5 \pm 401.5 \mathrm{cell} / \mu \mathrm{L})$, CD4+ T cell $(36.1 \pm 8.7 \% ; 657.1 \pm 189.9 \mathrm{cell} / \mu \mathrm{L})$, and a low CD4/CD8 value in women with EC $(1.4 \pm 0.5)$ and PC $(1.5 \pm 0.3)$ compared to NPC $(1.9 \pm 0.6)$ control $(p<05)$, while the total white

${ }^{*}$ Corresponding author.

How to cite this paper: Banda, J.M., Musa, B.O.P., Onyemelukwe, G.C., Shittu, S.O., Babadoko, A.A., Bakari, A.G., Mamman, A.I., Sarkin-Pawa, A. and Junaid, S.A. (2016) T Lymphocyte Subpopulations in Normal Pregnancies and Those Complicated by Eclampsia in Kaduna State, Nigeria. Open Journal of Immunology, 6, 93-100. http://dx.doi.org/10.4236/oji.2016.63010 
blood cell count, and differential percentage neutrophils count were noted to be elevated among the eclamptic women $\left(9.8 \pm 4.9 \times 10^{9} / \mathrm{L} ; 70.3 \pm 12.0 \%\right)$ compared to PC $\left(6.9 \pm 3.6 \times 10^{9} / \mathrm{L} ; 64.6 \pm\right.$ $8.1 \%)$ and NPC ( $\left.5.6 \pm 2.0 \times 10^{9} / \mathrm{L} ; 48.5 \pm 10.7 \%\right), \mathrm{p}<0.05$. Conclusion: Eclampsia was associated with significantly depressed CD3+ and CD4+ T lymphocyte, and increased percentage differential neutrophil counts.

\section{Keywords}

\section{Eclampsia, Preeclampsia, Pregnancy, T Cell Subpopulations}

\section{Introduction}

Eclampsia has remained a significant public health threat in both developed and developing countries, contributing to maternal and prenatal morbidity and mortality globally [1] [2]. However, the impact of the disease is felt more severely in developing countries including Nigeria. World Health Organization (WHO) reported that in Nigeria, 37,000 women die annually due to EC related complications. It accounts for up to $40 \%$ of maternal deaths in Northern Nigeria [3]. The International Society for the Study of Hypertension in Pregnancy (ISSHP) defines eclampsia (EC) as the occurrence of generalized convulsion(s) in association with signs of preeclampsia (PE)-hypertension and proteinuria during pregnancy, labor or 7 days after delivery [4]. Despite intensive research efforts, the etiology of EC is still unknown. Many hypotheses have been proposed to explain the mechanism of the disease. The most widely held is that an immunological mechanism is involved in the pathogenesis of the disease which includes numerical imbalance between $T$ helper cell and $T$ cytotoxic cell [5].

In pregnant women, local adaptation of the maternal immune system allows for successful coexistence between the mother and the semi-allograft that is the fetoplacental unit expressing both maternal (self) and paternal (nonself) genes [6]. Cytotoxic adaptive immune responses are diminished, bypassed, or even abrogated, while regulatory adaptive immunity is enhanced [7]. By contrast, innate (natural) immunity remains intact, serving two purposes: one, to continue to provide host defense against infection; and two, to interact with fetal tissues to promote successful placentation and pregnancy [8]. T cells are now recognized as CD4+ and CD8+ T-subsets based on their function and $\mathrm{T}$ cell receptor surface proteins [9]. These are measured in the laboratory manually (rosette method) and more recently by immunophenotyping (flow cytometry) using sheep erythrocyte receptor technique and monoclonal antibody [10] [11] respectively. The CD4+ and CD8+ T cells are otherwise known as, $\mathrm{T}$ "helper"/"inducer" and "suppressor"/“cytotoxic" $\mathrm{T}$ cells' based on their functional properties. A CD4/CD8 ratio of $1.8 \pm 0.6$ had been reported in the peripheral blood of apparently healthy individuals while imbalances were reported in immune disorders such as acquired immune deficiency syndrome (AIDS), autoimmune conditions, bacterial infections and helminth infections [11].

A numerical imbalance between helper and suppressor $\mathrm{T}$ lymphocytes has been demonstrated in various immunological based diseases by using monoclonal antibodies that identify subsets of $T$ cells [10]. What are the changes in CD3+, CD4+ and CD8+ T Lymphocytes as well as markers of inflammations (total white blood cell, neutrophils, lymphocytes and platelets) in patient with EC, normal healthy pregnancy and non-pregnant controls? This forms the basis of this study.

\section{Material and Methods}

\subsection{Study Area}

The participants were recruited from Labour wards, eclamptic site wards and the ANC, Labor ward/room and Family Planning Unit, after being assessed by competent clinicians within Ahmadu Bello University Teaching Hospita, Zaria, Hajiya Gambo Suwaba General Hospital Zaria, Barau Dikko Teaching Hospital Kaduna, Yusuf Dantsoho Memorial Hospital Tudun Wada, Kaduna and General Hospital Kafanchan.

\subsection{Study Design}

This was a comparative cross-sectional study and patients were taken as they present. 


\subsection{Ethical Approval}

Ethical clearance was obtained in September, 2012 from the Health Research Ethics Committee of the Ahmadu Bello University teaching hospital Shika-Zaria and the Kaduna State Ministry of Health (KSMOH) before commencing the study. Patients retained the right to deny consent for or opt out of the study at any stage without deny the services to be rendered. Patient's confidentiality was maintained throughout the study.

\subsection{Patients and Controls}

Third trimester pregnant women identified as Eclamptic $(\mathrm{EC} ; \mathrm{n}=38)$, normal healthy pregnant controls $(\mathrm{PC} ; \mathrm{n}=$ 38 ) age and parity matched and Healthy female non pregnant controls (NPC; $n=38$ ) age match with EC and PC are the participants in this study.

\subsubsection{Clinical Evaluation of Patients}

After obtaining an informed written consent, participants were evaluated and blood pressure measured by the collaborating clinician at the antenatal clinic (ANC)s of the Obstetrics and Gynecology Department of the respective hospitals. Participants who fulfilled the entry criteria were enrolled for the study. Participant's personal data such as age and parity, etc. were sourced from each participant and entered into the study standard form.

\subsubsection{Inclusion Criteria}

Inclusion criteria was according to the definition of EC by the International Society for the Study of Hypertension (ISSH) [12] [13], and this included seizure with other neurological symptoms like headache and visual disturbances, blood pressure $\geq 140 / 90 \mathrm{mmHg}$ on 2 separate occasions, 4 hours apart or a single recording of a diastolic blood pressure of $110 \mathrm{mmHg}$ in association with proteinuria, $\geq 2+$ on dipstick testing of random urine sample in a previously normotensive, non-proteinuric pregnant women after 20 weeks of gestation. Gestational age was determined at booking from the last menstrual period, by fundal height measurement or by ultrasonography.

Pregnant controls were recruited if they were in their third trimesters, age and parity matched with the eclamptics, whose blood pressure measurement was $<140 / 90$, nonproteinuric and has no known medical disorders.

Non-pregnant controls included normotensive $(\mathrm{Bp}<140 / 90)$ women with no known medical disorders attending the family planning clinic of the aforementioned hospitals.

\subsubsection{Exclusion Criteria}

Patients who did not fit in with the above criteria, refused consent or had concurrent HIV, malaria or other infections were excluded.

\subsection{Methods}

\subsubsection{Specimen Collection}

Three (3) mls of blood was drawn from each research participants on receipt of consent, after confirmation of diagnosis and before the administration of any drugs into ethylenediaminetetraacetic acid (EDTA) vacutainer tubes for the determination of $\mathrm{CBC}$ and $\mathrm{T}$ cell subsets.

\subsubsection{Laboratory-Based HIV Screening Test}

Nigerian established National algorithm for rapid serial HIV screening was used to rule out HIV infections in participants in this study. Commercially acquired immunochromatic test kits: Determine ${ }^{\mathrm{TM}}$ HIV1/2 Trinity Biotect, Japan Stat-Pak and Uni-Gold Recomigen HIV1/2 Trinity Biotech, Ireland serial tests were used according to manufacturer's instructions as obtained in the hospital's Standard Operating Procedure (SOP). Serum samples reactive for HIV by these tests were excluded from this study [14].

\subsubsection{Malaria Screening}

Malaria plasmodium parasites were detected by standard haematological procedure outlined in the standard 
text book of [15] as obtained in the respective Hospitals Standard Operating Procedure (SOP). Blood samples of participants that were blood smear positive for malaria plasmodium organisms were excluded from the study.

\subsubsection{Haematological Analysis}

Complete blood count was performed using KX-21N Haematology auto Analyzer (Sysmex, Kobe, Japan), a three-part a 3-part differential haematology analyzer to differentiate white blood cells into Neutrophils, Lymphocytes, and mixed population which consists of eosinophils, monocytes and basophils. Standardization, calibration of the instrument, and processing of the samples were done according to the manufacturer's instructions.

\subsubsection{Flow Cytometry of T Cell Subpopulations}

Flow cytometry of T lymphocytes was carried out using FACScount flow cytometer (BD, Biosciences) equipped with FACScount software for analysis. The T lymphocyte population was gated on the scatter plot as determined by the characteristic forward scatter (FS) and side scatter (SC) which indicates the cell size and shape respectively. The analysis was on absolute and percentage $\mathrm{CD} 3+, \mathrm{CD} 4+, \mathrm{CD} 8+\mathrm{T}$ cells using monoclonal anti T-lymphocytes antibodies (FITC-flouresceinisothiocyanate-labeled conjugate) $\mathrm{CD} 4 / \mathrm{CD} 3$ and $\mathrm{CD} 8 / \mathrm{CD} 3$, (BD, Bioscience Sanlose, CA 95131 USA). When whole blood was added to the reagents, the FITC-labelled antibodies in the reagent bind specifically to T lymphocytes surface antigens. After a fixative solution was added to the reagent tubes, the sample was run on the equipment. Here, the cells come in contact with laser light, which causes the flourescein-labeled cells to fluoresce. This fluorescent light provides the information necessary for the instrument to count the cells. In addition to containing the antibody reagent, the reagent tubes also contain known fluoroscein-integrated reference beads. These beads function as fluorescence standard for locating the lymphocytes and also as well as quantitation standard for the enumeration of cells. The software identifies the T-lymphocyte populations and calculates percentage and absolute counts. Results print immediately after sample is run, absolute and percentage cell counts for CD4+ ("helper/inducer" T-lymphocytes), CD8 "suppressor/cytotoxic" T-lymphocytes and CD3 (Total lymphocytes) as well as CD4/CD8 ("helper"/"suppressor" T-lymphocytes) ratio are reported.

\subsection{Method of Statistical Analysis}

The data obtained were analyzed using the SPSS version 20.0 (Chicago, USA). Results were expressed as mean \pm standard deviation and statistical significance was calculated using ANOVA with Post Hoc test. Comparisons were made between EC, PC and NPC. A p-value of less than 0.05 was considered to be significant.

\section{Results}

\subsection{Demographic Characteristics and Clinical Features of Participants}

In Table 1, the maternal age, gestational age and parity (mean \pm standard deviation [SD]) where similar for women with EC $(25.0 \pm 5.9$ years; $37.2 \pm 2.2$ weeks and $1.4 \pm 2.4)$ and normal healthy pregnant women $(24.9 \pm$ 5.7 years; $37.1 \pm 2.0$ weeks, and $1.5 \pm 2.5)$ years and normal healthy non pregnant women control $(25.1 \pm 5.9$ years). While the mean values of blood pressures (systolic; diastolic) and standard deviation were noted to be higher in EC $(171.6 \pm 25.2 \mathrm{mmHg} ; 110.0 \pm 10.7 \mathrm{mmHg})$ compared with normal healthy pregnant $(111.6 \pm 7.1$ $\mathrm{mmHg} ; 79.5 \pm 11.3 \mathrm{mmHg})$ and non pregnant controls $(109.6 \pm 6.6 ; 84.2 \pm 6.4 \mathrm{mmHg})$. There were significant differences between EC, PC and NPC ( $\mathrm{p}<0.05)$.

Most of the eclamptic women (55.3\%) were not booked in the facility at the time of study. While (100\%) of the pregnant women control had been booked who served as controls. Majority of the patients that did not book were said to have registered at private Clinics, Nursing homes or Primary Health Care Centers (PHC), but there were no records to authenticate their claims. Urinary proteins (albumin), $\geq 2+$ were recorded in all eclamptic women and non in PC and NPC. Tonic-clonic convulsions occurred ante partum and intrapatum in 16 (52.1\%) and $22(57.9 \%)$ in the eclamptic women, respectively. 
Table 1. The Demographics and Clinical characteristics of women included in the Study (Mean and SD).

\begin{tabular}{cccc}
\hline Characteristics & EC $(\mathrm{n}=38)$ & PC $(\mathrm{n}=38)$ & NPC $(\mathrm{n}=38)$ \\
\hline Age (years) & $25.0 \pm 5.9$ & $24.9 \pm 5.7$ & $25.1 \pm 5.9$ \\
Parity & $4.0 \pm 2.4$ & $1.5 \pm 2.5$ & NA \\
Gestational age (wks) & $37.2 \pm 2.2$ & $37.1 \pm 2.0$ & NA \\
BMI (Kg/m $\left.{ }^{2}\right)$ & $26.4 \pm 4.3$ & $25.8 \pm 3.7$ & $25.2 \pm 4.3$ \\
Systolic BP (mmHg) & $171.6 \pm 25.2^{*}$ & $111.6 \pm 7.1$ & $109.6 \pm 6.6$ \\
Diastolic BP (mmHg) & $110.0 \pm 10.7^{*}$ & $79.5 \pm 11.3$ & $84.2 \pm 6.4$ \\
Proteinuria & $\geq 2+$ & $\mathrm{ND}$ & $\mathrm{ND}$ \\
Antenatal booking & $55.3 \%$ & $100.0 \%$ & $\mathrm{NA}$ \\
Antepartum convulsion & $16(42.1 \%)$ & $\mathrm{NA}$ & $\mathrm{NA}$ \\
Intrapartum convulsion & $22(57.9 \%)$ & $\mathrm{NA}$ & $\mathrm{NA}$ \\
\hline
\end{tabular}

Key: $\mathrm{EC}=$ Eclampsia, $\mathrm{PC}=$ Pregnant Control, $\mathrm{NPC}=\mathrm{N}$ on Pregnant Control, $\mathrm{BMI}=$ Body Mass Index, $\mathrm{BP}=$ Blood Pressure, $\mathrm{NA}=\mathrm{Not}$ Applicable, $\mathrm{ND}=$ Not Detected, *Eclampsia is significantly different from both controls at $\mathrm{p}<0.05$ using ANOVA.

\subsection{Haematological Study of Participants}

The data in Table 2 show the haematological indices in patient with EC, PC and NPC:

The mean $\mathrm{Hb}$ and standard deviations were: EC $(10.9 \pm 1.9 \mathrm{~g} / \mathrm{dL}), \mathrm{NPC}(10.9 \pm 1.4 \mathrm{~g} / \mathrm{dL})$ and NPC $(11.2 \pm$ $1.2 \mathrm{~g} / \mathrm{dL})$. There was no significant difference between patient with EC and controls $(\mathrm{p}>0.05)$.

The total white blood cell count in EC $\left(9.8 \pm 4.9 \times 10^{9} / \mathrm{L}\right)$ was significantly higher than in $\mathrm{PC}(6.9 \pm 3.6 \times$ $\left.10^{9} / \mathrm{L}\right)$ and NPC $\left(5.6 \pm 2 \times 10^{9} / \mathrm{L}\right) \mathrm{p}>0.05$.

The mean differential lymphocyte count in patient with EC $(25.5 \pm 18.3 \%)$ displays progressive significant (p $<0.05)$ decreased from PC $(28.5 \pm 9.4 \%)$ to healthy NPC $(43.0 \pm 10.8 \%)$.

Significance increase in the mean value of neutrophils differential counts in patient with EC $(70.3 \pm 12.0 \%)$ compared with PC $(64.6 \pm 8.1 \%)$ and NPC $(48.5 \pm 10.7 \%) \mathrm{P}<0.05$ was recorded.

The mean platelet counts progressively decreased from the patients with EC $\left(195.8 \pm 91.6 \times 10^{9} / \mathrm{L}\right)$, to $\mathrm{PC}$ $\left(221.9 \pm 53.4 \times 10^{9} / \mathrm{L}\right)$ and to NPC $\left(225.2 \pm 63.7 \times 10^{9} / \mathrm{L}\right)$, but the decrease was not significant $(\mathrm{p}>0.05)$.

\subsection{The Subpopulations of T Lymphocytes in Study Participants.}

Total T cell subpopulations values in patient with EC as well as PC and NPC were captured in Table 3 as follows.

The mean percentage and absolute values of total $\mathrm{T}$ cells (CD3 $+\mathrm{T}$ cells) decreased from NPC (74.9 \pm $11.8 \% ; 1617.9 \pm 519.5 \mathrm{cell} / \mu \mathrm{L})$ to $\mathrm{NPC}(72.2 \pm 10.5 \% ; 1290.2 \pm 251.4 \mathrm{cell} / \mu \mathrm{L})$ and to patient with EC $(65.6$ $\pm 15.5 \% ; 1225.5 \pm 401.5$ cell $/ \mu \mathrm{L})$, respectively. The CD3\% decreased in EC is significantly different from both controls at $\mathrm{p}<0.05$, while the decrease in mean absolute values was significantly different from NPC at $\mathrm{p}<0.05$.

The percentage and absolute values of CD4+ T helper cells also decreased from NPC $(45.7 \pm 8.7 \% ; 999.9 \pm$ $278.4 \mathrm{cell} / \mu \mathrm{L})$, to $\mathrm{PC}(40.2 \pm 7.2 \% ; 718.5 \pm 158.7 \mathrm{cell} / \mu \mathrm{L})$ controls and to the women with $\mathrm{EC}(36.1 \pm 8.7 \%$; $657.1 \pm 189.9$ cell $/ \mu \mathrm{L})$, respectively. The mean values of CD4\% decrease in EC was significantly different from both controls at $\mathrm{p}<0.05$, while the mean absolute value of CD4+ T cells was significantly different from NPC at $\mathrm{p}<0.05$.

The mean percentage and absolute CD8+ T lymphocytes were: EC $(26.6 \pm 7.4 \% ; 492.9 \pm 196.1 \mathrm{cell} / \mu \mathrm{L})$ while those of PC and NPC were $(28.3 \pm 5.4 \% ; 495.9 \pm 124.7$ cell $/ \mu \mathrm{L})$ and $(25.2 \pm 6.6 \% ; 574.9 \pm 242.2 \mathrm{cell} / \mu \mathrm{L})$ respectively. There was no statistically significant difference between $\mathrm{EC}, \mathrm{PC}$ and NPC at $\mathrm{p}>0.05$.

The mean values for CD4+/CD8+ ratio in patient with EC $(1.4 \pm 0.5)$ while for PC and NPC, it was $1.5 \pm 0.3$ and $1.9 \pm 0.6$, significantly different, respectively. There was significant decrease in women with EC compare with NPC $(\mathrm{p}<0.05)$. 
Table 2. The hematological parameters of the women in the eclampsia study (Mean and SD).

\begin{tabular}{ccccc}
\hline Parameters. & EC $(\mathrm{n}=38)$ & PC $(\mathrm{n}=38)$ & NPC $(\mathrm{n}=38)$ & p-value \\
\hline Hemoglobin $\mathrm{g} / \mathrm{dL}$ & $10.9 \pm 1.9$ & $10.9 \pm 1.4$ & $11.2 \pm 1.2$ & 0.578 \\
White blood cell $\times 10^{9} / \mathrm{L}$ & $9.8 \pm 4.9$ & $6.9 \pm 3.6$ & $5.6 \pm 2.0^{*}$ & 0.001 \\
Lymphocyte (\%) & $25.5 \pm 18.3$ & $28.5 \pm 9.4$ & $43.0 \pm 10.8^{* *}$ & 0.001 \\
Neutrophil $(\%)$ & $70.3 \pm 12.0$ & $64.6 \pm 8.1$ & $48.5 \pm 10.7^{*}$ & 0.001 \\
Platelets $\times 10^{9} / \mathrm{L}$ & $195.8 \pm 91.6$ & $221.9 \pm 53.4$ & $225.2 \pm 63.7$ & 0.148 \\
\hline
\end{tabular}

Key: $\mathrm{EC}=$ Eclampsia, $\mathrm{PC}=$ Pregnant control, $\mathrm{NPC}=$ Non-pregnant, $\mathrm{n}=$ number of participants in each group, $\mathrm{SD}=\mathrm{Standard}$ deviation, $\%=$ percentage. *Eclampsia is significantly different from both controls at $\mathrm{p}<0.05$ (ANOVA). ${ }^{*}$ Eclampsia is significantly different from Non Pregnant Control at $\mathrm{p}<0.05$ (ANOVA).

Table 3. T-lymphocyte subsets in eclamptic study (Mean \pm SD).

\begin{tabular}{|c|c|c|c|c|}
\hline Parameters & $\mathrm{EC}(\mathrm{n}=38)$ & $\mathrm{PC}(\mathrm{n}=38)$ & $\mathrm{NPC}(\mathrm{n}=38)$ & p-value \\
\hline CD3 (\%) & $65.6 \pm 15.5$ & $72.2 \pm 10.5$ & $74.9 \pm 11.8^{*}$ & 0.006 \\
\hline CD3 (cell/ $\mu 1)$ & $1225.5 \pm 401.5$ & $1290.2 \pm 251.4$ & $1617.9 \pm 519.5^{* *}$ & 0.001 \\
\hline $\mathrm{CD} 4 \%$ & $36.1 \pm 8.7$ & $40.2 \pm 7.2$ & $45.7 \pm 8.7^{*}$ & 0.001 \\
\hline AbsCD4 (cell/ $\mu 1)$ & $657.1 \pm 189.9$ & $718.5 \pm 158.7$ & $999.9 \pm 278.4 * *$ & 0.001 \\
\hline CD8 (\%) & $26.6 \pm 7.4$ & $28.3 \pm 5.4$ & $25.2 \pm 6.6$ & 0.122 \\
\hline AbsCD8 (cell/ $\mu 1)$ & $492.9 \pm 196.1$ & $495.9 \pm 124.7$ & $574.9 \pm 242.2$ & 0.116 \\
\hline $\mathrm{CD} 4 / \mathrm{CD} 8$ ratio & $1.4 \pm 0.5$ & $1.5 \pm 0.3$ & $1.9 \pm 0.6 * *$ & 0.001 \\
\hline
\end{tabular}

Key: $\mathrm{CD}=$ Clusters of differentiation, $\mathrm{EC}=$ Eclampsia, $\mathrm{PC}=$ Pregnant control, $\mathrm{n}=$ number of study subject, $\mathrm{SD}=$ deviation, $\%=$ percentage. $* \mathrm{EC}$ is significantly different from both controls at $\mathrm{p}<0.05$ (ANOVA). ${ }^{*} \mathrm{EC}$ is significantly different from Non Pregnant Control at $\mathrm{p}<0.05$ (ANOVA).

\section{Discussion}

In this study the total WBC count was elevated in pregnant women with and without EC compared with NPC. Differential analyses further demonstrated that an increased in neutrophils, not lymphocytes, numbers account for the increased total leukocytes in EC. This finding agrees with that of Lurie et al. [16] in which increase in neutrophils count was reported in severe PE indicating an inflammatory response to the foetus or infection in the environment. Normal pregnancy involves many changes in the maternal physiology including alterations in hematological parameters. In general, white blood cell counts rise during pregnancy with the occasional appearance of myelocytes or metamyelocytes in the blood [17]. Leukocytosis is evidence of an increased inflammatory response during normal pregnancy and since women with evidence of infection were excluded in this study, the data of increased neutrophil count in EC may in part represent the severity of inflammatory response in eclampsia.

The CD3+ and CD4+ T lymphocytes in this study showed a steady decrease from NPC to PC to EC. Similarly, the CD4/CD8 ratio in EC was significantly lower than in PC and NPC $(\mathrm{p}<0.05)$ indicating increased CD8+ immune response in EC. This is similar to the reports of Musa et al. [18] and Tallon et al. [19] where absolute numbers of total $\mathrm{T}$ cells $(\mathrm{CD} 3+\mathrm{T})$ cells and $\mathrm{T}$ helper $(\mathrm{CD} 4+\mathrm{T})$ cells decreased significantly in the third trimester of eclamptic women compared to PC and NPC. Other previous work on T lymphocyte enumeration in pregnancy has produced inconsistent results showing decrease [20], increase [21] or no change [22]. The significant difference found in the T lymphocyte subsets in the peripheral blood of pregnant women with and without EC compared to NPC in this study could be as a result of the immunosuppressive effect of placental products such as pregnancy specific beta-1 glycoprotein [23] [24], progesterone or human chorionic Gonadotrophin [25]. Pregnancy is associated with inflammatory processes [26], which may result in increased expression of cell-adhesion-molecules (CAMs) that facilitate leukocyte extravasation to the tissue site where activation of the immune system occurs. Some researchers have proposed a redeployment or redistribution of T lymphocytes in the maternal blood circulation in pregnancy [25]. These may explain the depressed CD3+ and CD4+ lymphocytes secondary to decrease in lymphocytes recorded among the pregnant women with EC and normal healthy pregnant in relation to the non-pregnant control in this study, since women with infections such as malaria and HIV which is associated with depressed levels of CD4+ T lymphocytes were excluded. 


\section{Limitations}

Sample size was small compared to period of sampling due to the fact Eclampsia, being an emergency condition, most of the time drugs were administered before referral from lower facility to higher hospitals as management and treatment of Eclampsia in Nigeria follows a referral system. Again not all untreated eclamptic women were taken as HIV and malaria infected participants were excluded from the study.

The study was conducted at the health facilities. The data, being hospital based may thus not be easily extrapolated to the general population, but patient with untreated eclampsia.

\section{Conclusion}

Eclampsia was associated with significantly depressed CD3+ and CD4+ T lymphocyte, and increased percentage differential neutrophil counts. A longitudinal study is required so as to determine at what trimester the level of alterations in Neutrophil, CD3 + and CD $+\mathrm{T}$ cells becomes significant.

\section{References}

[1] WHO (2011) Recommendations for Prevention and Treatment of Preeclampsia and Eclampsia. WHO Department of Maternal and Child Health, Geneva.

[2] Ghulmiyyah, L. and Sibai, B. (2012) Maternal Mortality from Preeclampsia and Eclampsia. Seminars in Perinatology, 36, 56-59. http://dx.doi.org/10.1053/j.semperi.2011.09.011

[3] WHO (2004) Coverage of Maternity Care: A Listing of Available Information. World Health Organization, Geneva.

[4] Shah, A.K. (2009) Preeclampsia/Eclampsia. http://emedicine.medscape.com/article/118427-overview

[5] Rein, D.T., Schondorf, T., Gohring, U.J., Kurbacher, C.M., Pinto, I., Breidenbach, M., Mallmann, P., Kolhagen, H. and Angel, H. (2002) Cytokine Expression in Peripheral Blood Lymphocytes Indicates a Switchto T(Helper) Cells in Patients with Preeclampsia. Journal of Reproductive Immunology, 54, 133-142. http://dx.doi.org/10.1016/S0165-0378(01)00128-0

[6] Robertson, S.A. (2010) Immune Regulation of Conception and Embryo Implantation-All about Quality Control? Journal of Reproductive Immunology, 85, 51-57. http://dx.doi.org/10.1016/j.jri.2010.01.008

[7] Leber, A., Telse, A. and Zenclussen, A. (2010) Regulatory T Cells and Their Role in Pregnancy. American Journal of Reproductive Immunology, 63, 445-459. http://dx.doi.org/10.1111/j.1600-0897.2010.00821.x

[8] Zhang, J., Chen, Z., Smith, G.N. and Croy, B.A. (2011) Natural Killer Cell-Triggered Vascular Transformation: Maternal Are before Birth? Cellular and Molecular Immunology, 8, 1-11. http://dx.doi.org/10.1038/cmi.2010.38

[9] Swain, J.L. (1983) T Cell Subsets and the Recognition of MHC Class. Immunological Review, 74, 129-142. http://dx.doi.org/10.1111/j.1600-065X.1983.tb01087.x

[10] Romagnani, S. (1991) Human Th1 and Th2: Doubt No More. Immunology Today, 12, 256-257. http://dx.doi.org/10.1016/0167-5699(91)90120-I

[11] Bach, M.A. and Bach, J.E. (1981) The Use of Monoclonal Anti-T Cell Antibodies to Study T Cell Imbalances in Human Disease. Clinical and Experimental Immunology, 45, 449-456.

[12] Chesley, L.C. (1985) Diagnosis of Preeclampsia. Obstetrics and Gynecology, 65, 423-425.

[13] Ramsy, J.E., Jamieson, N., Greer, J.A. and Sasar, N. (2003) Paradoxical Elevation of Adeponectin Concentration in Women Preeclampsia. Hypertension, 42, 891-894. http://dx.doi.org/10.1161/01.HYP.0000095981.92542.F6

[14] Federal Ministry of Healthy (2008) Sero-Prevalence Sentinel Survey among Pregnant Women Attending Antenatal Clinics in Nigeria. A Technical Report, Federal Ministry of Health, National AIDS Control Programmes, 1-85.

[15] Dacie, J.V. and Lewis, S.M. (1991) Practical Haematology. 7th Edition, Churchil Livingstone, Edinburgh, 54-79.

[16] Lurie, S., Frenkel, E. and Tuvbin, Y. (1998) Comparison of the Differential Distribution of Leukocytes in Preeclampsia versus Uncomplicated Pregnancy. Gynecology and Obstetrics Investigations, 45, 229-231. http://dx.doi.org/10.1159/000009973

[17] England, J.M. and Bain, B.J. (1976) Total and Differential Leucocyte Count. Britain Journal of Haematology, 33, 1-7. http://dx.doi.org/10.1111/j.1365-2141.1976.tb00966.x

[18] Musa, B., Onyemelukwe, G., Olatunji, O., Odogwu, K., Hambolu, J. and Kene, T. (2012) Serum Cytokine Levels and T Lymphocytes Subsets in Pregnant Women with Eclampsia. Open Journal of Immunology, 2, 116-124. http://dx.doi.org/10.4236/oji.2012.23014

[19] Tallon, D.F., Darach Corcooran, D.J., O’Dwyer, E.M. and Greally, J.F. (1984) Circulating Lymphocyte Subpopulation 
in Pregnancy: A Longitudinal Study. The Journal of Immunology, 132, 1784-1787.

[20] Sulmer, R. and Ranock, W. (1977) Depletion of Circulating T Lymphocytes in Pregnancy. Clinical and Experimental Immunology, 20, 302-305.

[21] Clements, I.J., Yu, D.T.Y., Levy, J. and Pearson, C.R. (1978) Human Lymphocyte Subpopulation. The Effect of Pregnancy. Proceedings of the Society of Experimental Biology and Medicine, 152-664.

[22] Birkeland, S.A. and Kristofferson, K. (1979) Preeclampsia-A State Mother-Fetus Immune Imbalance. The Lancet, 2 , 720-725. http://dx.doi.org/10.1016/S0140-6736(79)90645-7

[23] Onyemelukwe, G.C., Ekwempu, C.C. and Alexander, L.C. (1985) Pregnancy Specific Glycoprotein (PSG1) in Normal Pregnancy in Nigeria. Internal Journal of Obstetrics and Gynaecology, 23, 347-349. http://dx.doi.org/10.1016/0020-7292(85)90032-3

[24] Blanchon, L., Bocco, J.L., Gallot, D., Gachon, A., Lemery, D., Dechelotte, P., Dastugue, B. and Sapin, V. (2001) CoLocalization of KLF6 and KLF4 with Pregnancy-Specific Glycoproteins during Human Placenta Development. Mechanism of Development, 105, 185-189. http://dx.doi.org/10.1016/S0925-4773(01)00391-4

[25] Jenkins, D.M. (1977) Immunological Aspects of Pregnancy Hypertension. Clinical Obstetrics and Gynecology, 4, 665684.

[26] Mor, G. and Cardenas, I. (2010) The Immune System in Pregnancy: A Unique Complexity. American Journal of Reproductive Immunology, 63, 425-433. http://dx.doi.org/10.1111/j.1600-0897.2010.00836.x

\section{Submit or recommend next manuscript to SCIRP and we will provide best service for you:}

Accepting pre-submission inquiries through Email, Facebook, LinkedIn, Twitter, etc.

A wide selection of journals (inclusive of 9 subjects, more than 200 journals)

Providing 24-hour high-quality service

User-friendly online submission system

Fair and swift peer-review system

Efficient typesetting and proofreading procedure

Display of the result of downloads and visits, as well as the number of cited articles

Maximum dissemination of your research work

Submit your manuscript at: http://papersubmission.scirp.org/ 